\title{
The Crystal Structure of Diazidodipyridinecadmium $\left[\mathrm{Cd}\left(\mathrm{N}_{3}\right)_{2}\left(\mathrm{C}_{5} \mathrm{H}_{5} \mathrm{~N}\right)_{2}\right]$
}

\author{
I NGELA A GRELL
}

Department of Inorganic Chemistry, Chalmers University of Technology and the University of Göteborg, P.O.Box, S-402 20 Göteborg 5, Sweden

\begin{abstract}
The crystal structure of diazidodipyridinecadmium $\left[\mathrm{Cd}\left(\mathrm{N}_{3}\right)_{2}\right.$ $\left(\mathrm{C}_{5} \mathrm{H}_{5} \mathrm{~N}\right)_{2}$ ] has been determined by single crystal $\mathrm{X}$-ray diffraction methods.

The crystals are tetragonal and belong to the space group $I 4_{1} / a$ (No. 88). The unit cell contains eight formula units and has the dimensions $a=b=15.795 \pm 0.001 \quad \AA, c=10.148 \pm 0.002 \AA$, and $V=2531.9 \AA^{3}$. The cadmium atom is octahedrally coordinated by six ligand nitrogen atoms at distances of $2.336 \pm 0.017 \AA, 2.349 \pm 0.012 \AA$, and $2.352 \pm 0.016 \AA$. These octahedra are linked together by the azide groups to form a three-dimensional net. The azide groups are linear and appear to be symmetrical, the nitrogen-nitrogen distances being $1.167 \pm 0.020 \AA$ and $1.141 \pm 0.021 \AA$.

The $R$-value of the proposed structure is 0.056 .

The infrared spectrum of $\left[\mathrm{Cd}\left(\mathrm{N}_{3}\right)_{2}\left(\mathrm{C}_{5} \mathrm{H}_{5} \mathrm{~N}\right)_{2}\right]$ has also been registered and discussed.
\end{abstract}

\begin{abstract}
A series of investigations of the crystal and molecular structures of a group

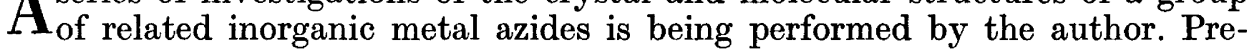
viously, the crystal structures of $\left[\mathrm{Cu}\left(\mathrm{N}_{3}\right)_{2}\left(\mathrm{NH}_{3}\right)_{2}\right],{ }^{1} \mathrm{Cu}\left(\mathrm{N}_{3}\right)_{2},{ }^{2,3}\left[\mathrm{Cu}\left(\mathrm{N}_{3}\right)_{2}\left(\mathrm{C}_{5} \mathrm{H}_{5} \mathrm{~N}\right)_{2}\right],{ }^{4}$ and $\left[\mathrm{Zn}\left(\mathrm{N}_{3}\right)_{2}\left(\mathrm{C}_{5} \mathrm{H}_{5} \mathrm{~N}\right)_{2}\right]^{5}$ have been determined, while the crystal structure of $\left[\mathrm{Cd}\left(\mathrm{N}_{3}\right)_{2}\left(\mathrm{C}_{5} \mathrm{H}_{5} \mathrm{~N}\right)_{2}\right]$ is described in this paper. A zinc-azide-ammine complex is now also being investigated.

The compound $\left[\mathrm{Cd}\left(\mathrm{N}_{3}\right)_{2}\left(\mathrm{C}_{5} \mathrm{H}_{5} \mathrm{~N}\right)_{2}\right]$ was first prepared by Curtius and Rissom, ${ }^{6}$ who described their product as colourless, blunt-shaped crystals, which rapidly turned yellow in air. Later, long, needle-shaped crystals of $\left[\mathrm{Cd}\left(\mathrm{N}_{3}\right)_{2}\left(\mathrm{C}_{5} \mathrm{H}_{5} \mathrm{~N}\right)_{2}\right]$ were prepared by Strecker and Schwinn ${ }^{7}$ from $\left[\mathrm{CdCl}_{2}\left(\mathrm{C}_{5} \mathrm{H}_{5} \mathrm{~N}\right)_{2}\right], \mathrm{C}_{5} \mathrm{H}_{5} \mathrm{~N}$, and $\mathrm{NaN}_{3}$.
\end{abstract}

\section{EXPERIMENTAL}

Preparation. Crystals were prepared by several different methods, but those most suitable for a single crystal X-ray investigation were obtained by pouring stoichiometric amounts of first pyridine and then $\mathrm{NaN}_{3}$ into a $0.5 \mathrm{M}$ solution of $\mathrm{Cd}\left(\mathrm{NO}_{3}\right)_{2}$. The precipitate 
formed was dissolved in pyridine heated to about $80^{\circ}$. On cooling, colourless, pyramidal crystals, unstable in air, appeared..$^{10}$

Analysis. The amount of cadmium in $\left[\mathrm{Cd}\left(\mathrm{N}_{3}\right)_{2}\left(\mathrm{C}_{5} \mathrm{H}_{5} \mathrm{~N}\right)_{2}\right]$ was determined by titration with EDTA, ${ }^{3}$ and the azide content by titration with a Ce(IV)-solution.' The following results were obtained: $\mathrm{Cd}$ 31.5, $\mathrm{N}_{3}-22.0$. Calc. for $\left[\mathrm{Cd}\left(\mathrm{N}_{3}\right)_{8}\left(\mathrm{C}_{5} \mathrm{H}_{5} \mathrm{~N}\right)_{8}\right]: \mathrm{Cd} 31.7, \mathrm{~N}_{3}-23.7$. The structure determination confirms, moreover, that $\left[\mathrm{Cd}\left(\mathrm{N}_{8}\right)_{2}\left(\mathrm{C}_{5} \mathrm{H}_{5} \mathrm{~N}\right)_{2}\right]$ is the true formula of the product prepared.

\section{STRUCTURE INVESTIGATION}

$X$-Ray methods. The single crystals of $\left[\mathrm{Cd}\left(\mathrm{N}_{3}\right)_{2}\left(\mathrm{C}_{5} \mathrm{H}_{5} \mathrm{~N}\right)_{2}\right]$, used to collect the intensity data, were pyramidal, the crystallographic $c$-axis being perpendicular to the base of the pyramid. The dimensions of the basal plane were of the magnitude of $0.18 \times 0.18 \mathrm{~mm}$, and the height of the pyramid was approximately $0.10 \mathrm{~mm}$. Because the crystals were rather unstable in air, six different crystals had to be used.

Weissenberg photographs were registered for $h k 0-h k 3, h k 5$, and $h 0 l$, using $\mathrm{CuKa}$-radiation and multiple film equi-inclination techniques. Because of the large absorption with CuK $\alpha$-radiation $\left(\mu=155.1 \mathrm{~cm}^{-1}\right)$ a new set of equiinclination Weissenberg photographs was taken for nine zones ( $h k 0-h k 8)$ using $\mathrm{Zr}$-filtered MoK$\alpha$-radiation $\left(\mu=18.4 \mathrm{~cm}^{-1}\right)$.

In order to determine accurate cell dimensions, $\mathrm{X}$-ray powder photographs of $\left[\mathrm{Cd}\left(\mathrm{N}_{3}\right)_{2}\left(\mathrm{C}_{5} \mathrm{H}_{5} \mathrm{~N}\right)_{2}\right]$ were taken in a Guinier focusing camera, using $\mathrm{CuK} \alpha_{1}$ radiation $(\lambda=1.54050 \AA)$ and $\mathrm{Pb}\left(\mathrm{NO}_{3}\right)_{2}(a=7.8564 \AA){ }^{22}$ as an internal standard.

Unit cell and space group. From the Weissenberg photographs the crystals were seen to be tetragonal, belonging to the Laue group $4 / \mathrm{m}$. The approximate cell dimensions obtained from these photographs were refined using the Guinier photographs, the $\sin ^{2} \theta_{\text {obs }}$-values being obtained from the measured $s$-values using the programme PEPP. ${ }^{11}$ The refinement of the cell dimensions was performed with the programme POWDER ${ }^{12}$ and the following values were obtained: $a=b=15.795 \pm 0.001 \AA, c=10.148 \pm 0.002 \AA$, and $V=2531.9 \AA^{3}$. Observed and calculated $\sin ^{2} \theta$-values are given, together with observed and calculated intensities, in Table 1.

A measure of the density of the crystals was obtained by the flotation method, using mixtures of $\mathrm{CHBr}_{3}$ and $\mathrm{C}_{6} \mathrm{H}_{5} \mathrm{Cl}$. The density was determined to be $2.0 \mathrm{~g} / \mathrm{cm}^{8}$, which corresponds to eight formula units per unit cell $\left(\varrho_{\text {calc }}=1.86 \mathrm{~g} / \mathrm{cm}^{3}\right)$.

It was obvious from the $\mathrm{X}$-ray photographs that the following general conditions were obeyed for all reflections: $h k l: h+k+l=2 n ; h k 0: h=2 n$; $00 l: l=4 n$. This is in accordance with space group $I 4_{1} / a$ (No. 88). ${ }^{22}$

Determination of the structure. The intensities of the reflections recorded both with $\mathrm{CuK} \alpha$-radiation and with $M o K \alpha$-radiation were estimated visually by comparison with a standard scale. The values obtained were corrected for Lorentz and polarisation effects using the programme DATA P2. ${ }^{12}$ No corrections were applied for absorption. There were thus serious absorption errors in the data collected with $\mathrm{Cu} K \alpha$-radiation $(\mu R \approx 1.40)$ and these data were therefore not used in the final calculations. Absorption errors in the data collected with $M o K \alpha$-radiation were, however, considered to be negligible $(\mu R \approx 0.17)$. 
Table 1. X-Ray powder diffraction data for $\left[\mathrm{Cd}\left(\mathrm{N}_{3}\right)_{2}\left(\mathrm{C}_{5} \mathrm{H}_{5} \mathrm{~N}\right)_{2}\right]$. Guinier camera. $\mathrm{Cu} K \alpha_{1}$ radiation $(\lambda=1.54050 \AA)$.

\begin{tabular}{|c|c|c|c|c|}
\hline$h k l$ & $10^{6} \sin ^{2} \theta_{o b s}$ & $10^{6} \sin ^{2} \theta_{\text {calc }}$ & $I_{\mathrm{obs}}$ & $\underset{\text { rel. scale }}{I_{\text {calc }}}$ \\
\hline \multirow{13}{*}{$\left.\begin{array}{lll}1 & 0 & 1 \\
2 & 1 & 1 \\
1 & 2 & 1 \\
2 & 2 & 0 \\
3 & 0 & 1 \\
2 & 0 & 2 \\
3 & 2 & 1 \\
2 & 3 & 1 \\
2 & 2 & 2 \\
4 & 1 & 1 \\
1 & 4 & 1 \\
3 & 1 & 2 \\
1 & 0 & 3 \\
2 & 1 & 3 \\
1 & 2 & 3\end{array}\right\}$} & 8162 & 8138 & st & 641 \\
\hline & 17653 & 17650 & st & 580 \\
\hline & 19010 & 19024 & st & 625 \\
\hline & 27142 & 27162 & $\mathrm{~m}$ & 212 \\
\hline & 32510 & 32554 & st & 446 \\
\hline & 36662 & 36674 & st & 295 \\
\hline & 42014 & 42066 & st & 310 \\
\hline & 46186 & 46186 & st & 188 \\
\hline & 46770 & 46822 & $\mathbf{w}$ & 13 \\
\hline & 54247 & 54222 & $\mathrm{w}$ & 24 \\
\hline & 63689 & 63734 & $\mathbf{w}$ & 64 \\
\hline & & 65210 & & 70 \\
\hline & 00188 & 05210 & $\mathbf{w}$ & 70 \\
\hline \multirow{6}{*}{$\left.\begin{array}{lll}4 & 2 & 2 \\
2 & 4 & 2 \\
2 & 5 & 1 \\
4 & 4 & 0 \\
3 & 2 & 3 \\
0 & 0 & 4 \\
4 & 1 & 3 \\
1 & 4 & 3\end{array}\right\}$} & 70552 & 70602 & st & 340 \\
\hline & 74694 & 74722 & m & 127 \\
\hline & 76043 & 76096 & $\mathbf{m}$ & 100 \\
\hline & 82692 & $\begin{array}{l}82758 \\
92167\end{array}$ & $\mathbf{m}$ & 124 \\
\hline & 92260 & 092101 & $\mathrm{~m}$ & 132 \\
\hline & & 92270 & & \\
\hline $\left.\begin{array}{lll}6 & 1 & 1 \\
1 & 6 & 1\end{array}\right\}$ & 93708 & 93746 & w & 49 \\
\hline \multirow{6}{*}{$\left.\begin{array}{lll}6 & 2 & 0 \\
2 & 6 & 0 \\
5 & 4 & 1 \\
4 & 5 & 1 \\
6 & 0 & 2 \\
2 & 2 & 4 \\
5 & 0 & 3 \\
4 & 3 & 3 \\
3 & 4 & 3\end{array}\right\}$} & 95141 & 95120 & $\mathbf{w}$ & 75 \\
\hline & 103264 & 103258 & $\mathbf{m}$ & 113 \\
\hline & 108646 & 108650 & m & 99 \\
\hline & & 111191 & & \\
\hline & 111247 & & st & 205 \\
\hline & & 111294 & & \\
\hline 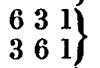 & 112768 & 112770 & $\mathbf{w}$ & 39 \\
\hline \multirow{2}{*}{$\left.\begin{array}{lll}5 & 2 & 3 \\
2 & 5 & 3 \\
7 & 0 & 1\end{array}\right\}$} & 120756 & 120806 & $\mathbf{w}$ & 33 \\
\hline & 122250 & 122282 & $\mathbf{w}$ & 34 \\
\hline \multirow{2}{*}{$\left.\begin{array}{lll}4 & 0 & 4 \\
7 & 2 & 1 \\
2 & 7 & 1\end{array}\right\}$} & 130292 & 130216 & $\mathbf{w}$ & 45 \\
\hline & 131764 & 131794 & $\mathbf{w}$ & 25 \\
\hline \multirow{4}{*}{$\left.\begin{array}{lll}6 & 1 & 3 \\
1 & 6 & 3 \\
6 & 4 & 2 \\
4 & 6 & 2 \\
5 & 4 & 3 \\
4 & 5 & 3 \\
6 & 5 & 1 \\
5 & 6 & 1\end{array}\right\}$} & 139817 & 139830 & $\mathbf{w}$ & 45 \\
\hline & 146714 & 146698 & $\mathrm{~m}$ & 93 \\
\hline & 149279 & 149342 & $\mathbf{w}$ & 29 \\
\hline & 150837 & 150819 & $\mathbf{w}$ & 29 \\
\hline
\end{tabular}

Acta Chem. Scand. 24 (1970) No. 10 
Table 1. Continued.

\begin{tabular}{|c|c|c|c|c|}
\hline $\left.\begin{array}{lll}7 & 4 & 1 \\
4 & 7 & 1 \\
8 & 1 & 1 \\
1 & 8 & 1\end{array}\right\}$ & 160350 & 160331 & $\mathbf{w}$ & 33 \\
\hline 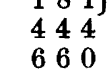 & $\begin{array}{l}168223 \\
171216\end{array}$ & $\begin{array}{l}168264 \\
171216\end{array}$ & $\begin{array}{l}\mathbf{w} \\
\mathbf{w}\end{array}$ & $\begin{array}{l}34 \\
23\end{array}$ \\
\hline $\left.\begin{array}{lll}7 & 2 & 3 \\
2 & 7 & 3\end{array}\right\}$ & 177820 & 177878 & $w$ & 26 \\
\hline $\left.\begin{array}{lll}8 & 2 & 2 \\
2 & 8 & 2\end{array}\right\}$ & 184729 & 184746 & $\mathbf{w}$ & 65 \\
\hline $\left.\begin{array}{llll}6 & 2 & 4 \\
2 & 6 & 4\end{array}\right\}$ & 187201 & 187288 & $\mathbf{w}$ & 68 \\
\hline $\left.\begin{array}{lll}8 & 4 & 0 \\
4 & 8 & 0 \\
7 & 6 & 1\end{array}\right\}$ & 190173 & 190240 & $\mathbf{w}$ & 75 \\
\hline $\left.\begin{array}{lll}6 & 7 & 1 \\
9 & 2 & 1 \\
2 & 9 & 1\end{array}\right\}$ & 207909 & 207891 & $\mathbf{w}$ & 33 \\
\hline 804 & 244379 & 244360 & $\mathrm{w}$ & 37 \\
\hline $\left.\begin{array}{lll}8 & 4 & 4 \\
4 & 8 & 4\end{array}\right\}$ & 282319 & 282408 & $\mathbf{w}$ & 24 \\
\hline 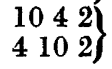 & 298920 & 298891 & $\mathrm{w}$ & 29 \\
\hline
\end{tabular}

Calculations were commenced using the set of intensity data available at that time, i.e. that recorded with $\mathrm{CuK} \alpha$-radiation. A three-dimensional Patterson summation based on the reflections $h k 0-h k 3$, and $h k 5$, was calculated, using the programme DRF. ${ }^{12}$ Approximate scale factors for the different layers were obtained from a comparison of the common reflections in the $h k 0-h k 3, h k 5$ layers, and the $h 0 l$ layer.

On a closer examination of the films it was apparent that, apart for a few weak reflections, the following conditions of reflection were also obeyed for the layers with $l$ even: $h k l: h, k=2 n$ and $h+k+l=4 n$. This is in accordance with the conditions of reflection for two of the eight-fold special positions in space group $I 4_{1} / a$, both these positions requiring a centrosymmetrical point symmetry. The cadmium atom was therefore assumed to be situated in such a centro-symmetrical position. The origin was placed at the centre of symmetry at $0,1 / 4,1 / 8$ from the inversion centre of the $\overline{4}$-axis, and the cadmium atom was assigned the eight-fold position $8 c$ with $x=0, y=0$, and $z=0$, which was in agreement with the largest peaks observed in the Patterson space.

Using the signs of the structure factors thus obtained, an electron density projection on (001) ( $c f$. Fig. 1) and a three-dimensional electron density function were calculated. From the latter electron density distribution it was possible to locate the azide group, the nitrogen atoms of which were situated in the sixteen-fold position $16 f$.

Using the approximate coordinates of these nitrogen atoms and with the known position of the cadmium atom, a three-dimensional difference electron density function was calculated. From geometrical considerations, assuming 
Fig. 1. Electron density projection of $\left[\mathrm{Cd}\left(\mathrm{N}_{3}\right)_{2}\left(\mathrm{C}_{5} \mathrm{H}_{5} \mathrm{~N}\right)_{2}\right]$ along the $c$-axis. Arbitrary units. Final positions of the atoms indicated.

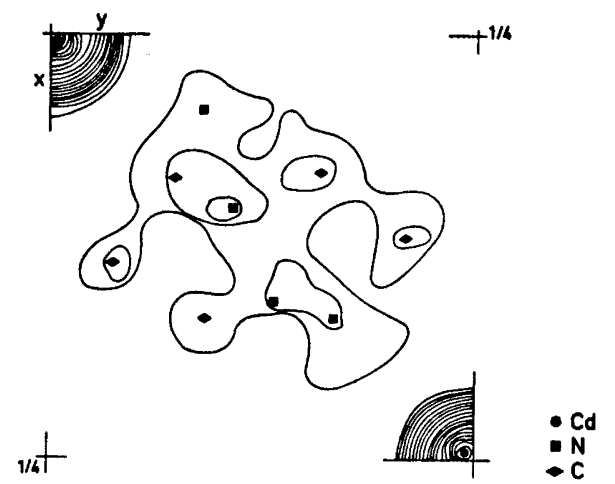

an octahedral environment about the cadmium atom, the approximate coordinates of the nitrogen atom of the pyridine ring could be estimated. This position agreed well with a peak in the difference electron density distribution which was slightly higher than the others. The carbon atoms were then located in the difference electron density map, with the help of geometrical considerations, using the known dimensions of the pyridine ring.

Approximate coordinates were thus obtained for all ligand atoms, all of which are situated in the sixteen-fold position $16 \mathrm{f}$.

Refinement of the structure. The structural parameters were refined by means of least squares calculations using the programme LALS. ${ }^{12}$ In the first stages of the refinement the data collected with $\mathrm{CuK} \alpha$-radiation were used. Atomic coordinates and isotropic temperature factors were refined for all atoms, which entailed a total of 42 parameters. The refinement converged to give an $R$-value of 0.075 (289 independent reflections).

At this stage the intensity data from the $h k 0-h k 8$ layers (443 independent reflections), collected with MoK $\alpha$-radiation, were available. The final cycles of refinement, using the full matrix-programme, were therefore based on this set of data. All atoms were refined anisotropically, the relativistic Hartree-Fock $\mathrm{X}$-ray scattering factors ${ }^{13}$ were used, and Cruickshank's weighting scheme $\left(w^{-1}=a+F_{\mathrm{o}}+c F_{\mathrm{o}}^{2}\right)$ was employed with the constants $a=10.0$ and $c=0.015$. The total number of parameters was 88. When the parameter shifts were less than $1 \%$ of the standard deviations the refinement was terminated. The $R$-value was then 0.056 , and a final difference electron density map showed no spurious peaks.

The resulting atomic parameters are given in Table 2, and observed and calculated structure factors are listed in Table 3. Distances and angles, calculated by the programme DISTAN, ${ }^{12}$ are given in Tables 4 and 5 .

\section{IR-SPECTRUM OF $\left[\mathrm{Cd}\left(\mathrm{N}_{3}\right)_{2}\left(\mathrm{C}_{5} \mathrm{H}_{5} \mathrm{~N}\right)_{2}\right]$}

The IR-spectrum of $\left[\mathrm{Cd}\left(\mathrm{N}_{3}\right)_{2}\left(\mathrm{C}_{5} \mathrm{H}_{5} \mathrm{~N}\right)_{2}\right]$, registered on a Beckman IR 9 spectrophotometer, using the $\mathrm{KBr}$ technique, is shown in Fig. 2. Most of the bands originate from pyridine, but it is also possible to indentify those bands 


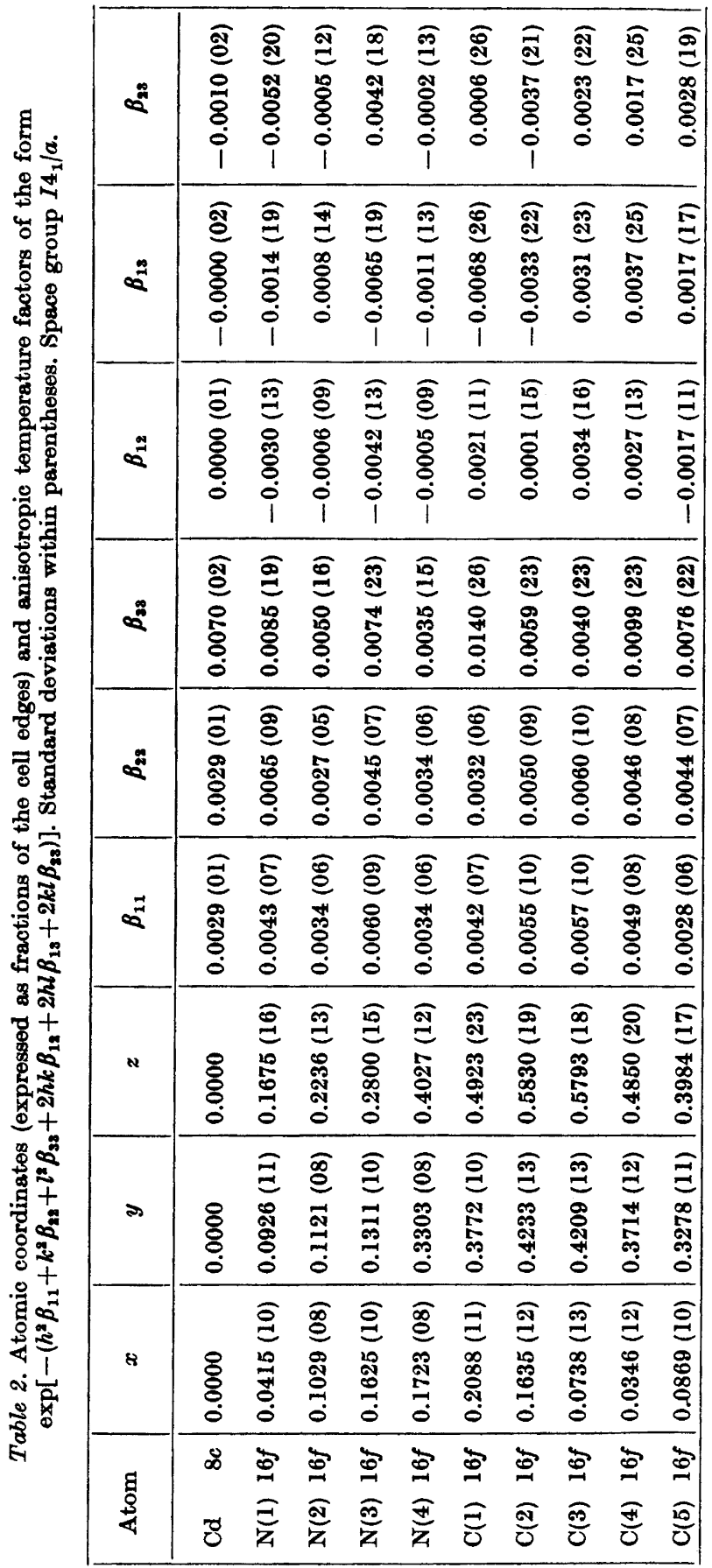

Acta Chem. Scand. 24 (1970) No. 10 
Table 3. Observed and calculated structure factors for $\left[\mathrm{Cd}\left(\mathrm{N}_{3}\right)_{2}\left(\mathrm{C}_{5} \mathrm{H}_{5} \mathrm{~N}\right)_{2}\right]$. The columns are $k,\left|F_{\mathrm{o}}\right|$, and $\left|F_{\mathrm{c}}\right|$, respectively. Unobserved reflexions deneted by a dash.

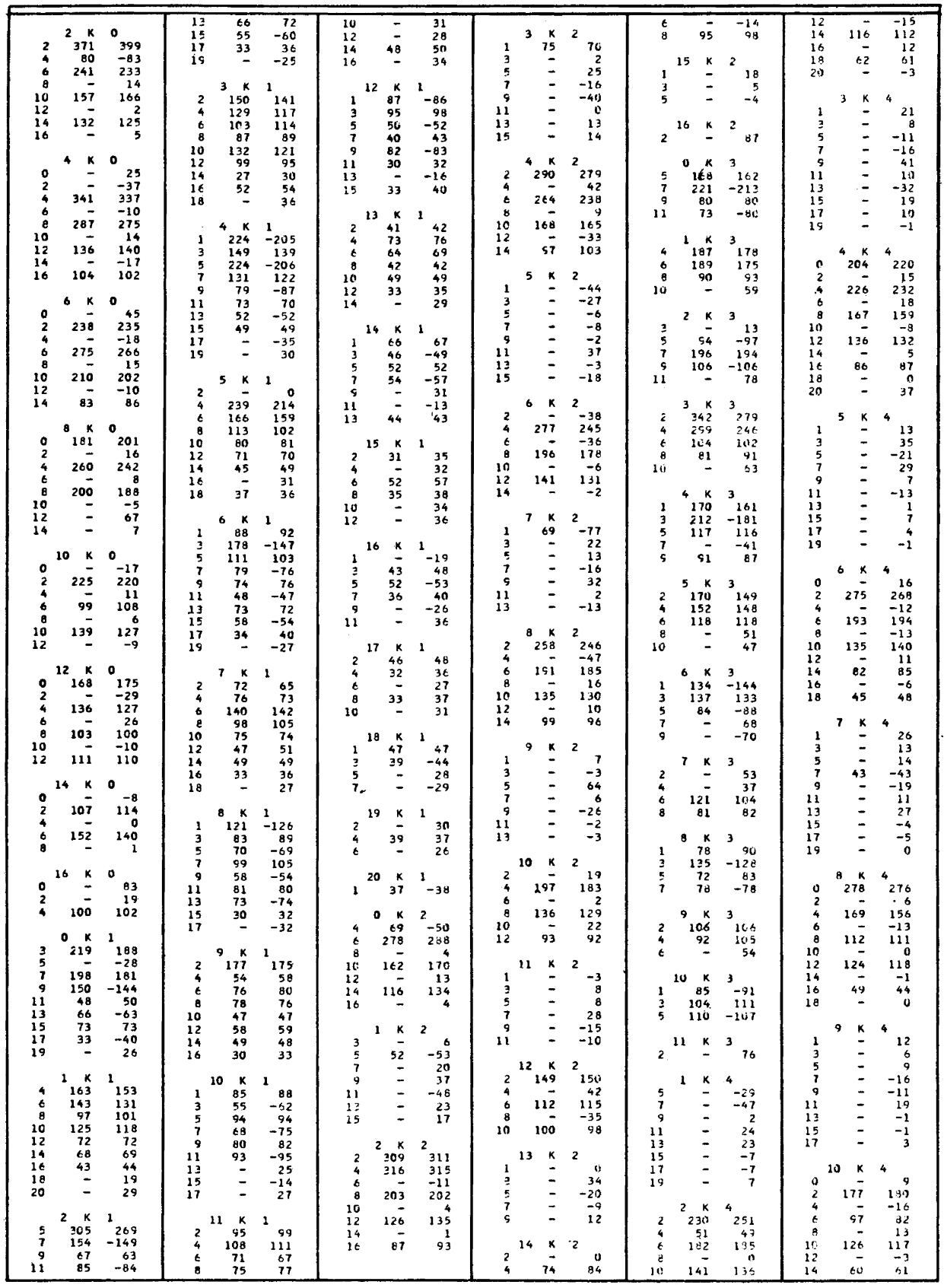

Acta Chem. Scand. 24. (1970) No. 10 
Table 3. Continued.

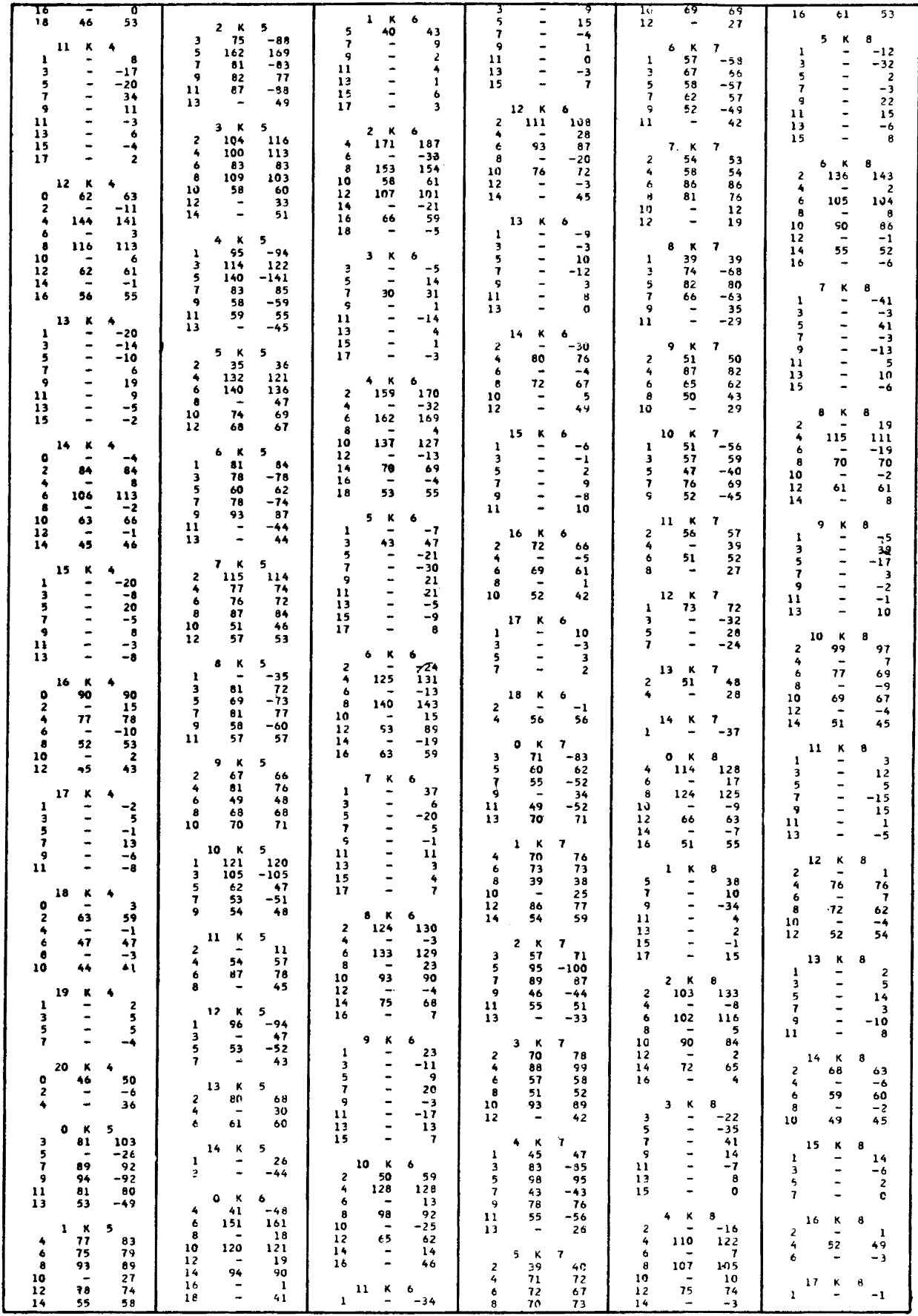


Table 4. Interatomic distances in $\left[\mathrm{Cd}\left(\mathrm{N}_{3}\right)_{2}\left(\mathrm{C}_{5} \mathrm{H}_{5} \mathrm{~N}\right)_{2}\right]$. Standard deviations within parentheses. Numbers enclosed in square brackets indicate fractional atomic coordinates.

a) $\mathrm{Cd}-\mathrm{N}$ distances within the coordination sphere

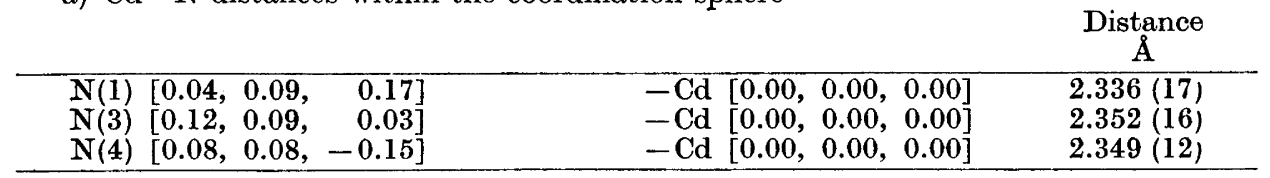

b) $\mathrm{N}-\mathrm{N}$ distances within the azide groups

\begin{tabular}{lllll}
\hline $\mathrm{N}(2)[0.10,0.11$, & $0.22]$ & $-\mathrm{N}(1)[0.04,0.09,0.17]$ & $1.167(20)$ \\
$\mathrm{N}(3)[0.16,0.13$, & $0.28]$ & $-\mathrm{N}(2)[0.10,0.11,0.22]$ & $1.141(21)$ \\
$\mathrm{N}(3)[0.16,0.13$, & $0.28]$ & $-\mathrm{N}(1)[0.04,0.09,0.17]$ & $2.308(22)$ \\
\hline
\end{tabular}

c) $\mathrm{N}-\mathrm{C}$ and $\mathrm{C}-\mathrm{C}$ distances within the pyridine ring

\begin{tabular}{lllll}
\hline $\mathrm{C}(1)[0.21,0.38$, & $0.49]$ & $-\mathrm{N}(4)[0.17,0.33,0.40]$ & $1.306(24)$ \\
$\mathrm{C}(5)[0.09,0.33$, & $0.40]$ & $-\mathrm{N}(4)[0.17,0.33,0.40]$ & $1.350(20)$ \\
$\mathrm{C}(2)[0.16,0.42$, & $0.58]$ & $-\mathrm{C}(1)[0.21,0.38,0.49]$ & $1.375(28)$ \\
$\mathrm{C}(3)[0.07,0.42$, & $0.58]$ & $-\mathrm{C}(2)[0.16,0.42,0.58]$ & $1.417(28)$ \\
$\mathrm{C}(4)[0.03,0.37$, & $0.49]$ & $-\mathrm{C}(3)[0.07,0.42,0.58]$ & $1.382(28)$ \\
$\mathrm{C}(5)[0.09,0.33$, & $0.40]$ & $-\mathrm{C}(4)[0.03,0.37,0.49]$ & $1.389(26)$ \\
\hline
\end{tabular}

d) Selected distances other than bond distances

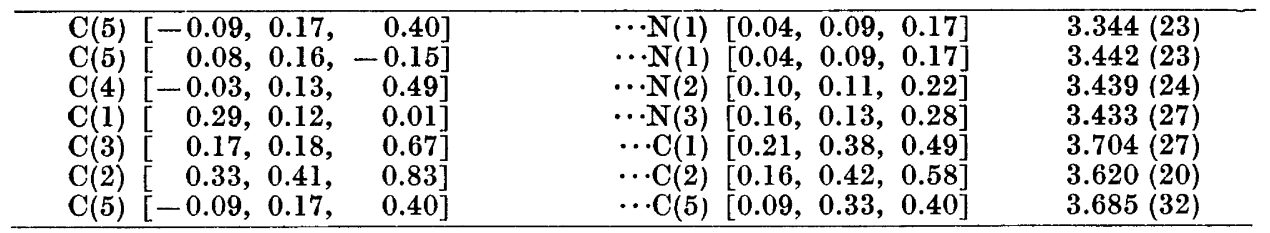

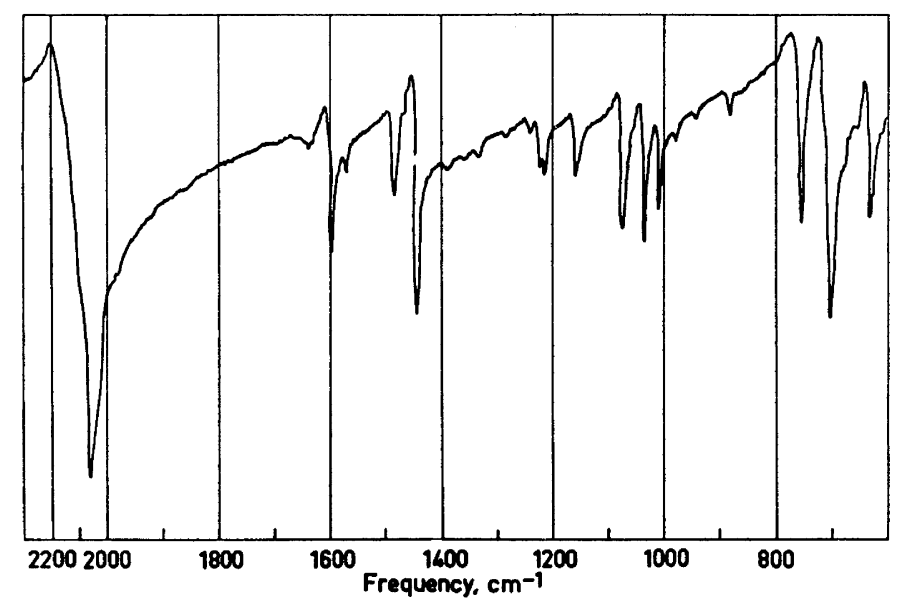

Fig. 2. Infrared spectrum of $\left[\mathrm{Cd}\left(\mathrm{N}_{3}\right)_{2}\left(\mathrm{C}_{5} \mathrm{H}_{5} \mathrm{~N}\right)_{2}\right]$. (The monochromator was changed at $2000 \mathrm{~cm}^{-1}$.)

Acta Chem. Scand. 24 (1970) No. 10 
Table 5. Angles in $\left[\mathrm{Cd}\left(\mathrm{N}_{3}\right)_{2}\left(\mathrm{C}_{5} \mathrm{H}_{5} \mathrm{~N}\right)_{2}\right]$. Notation as in Table 4.

a) $\mathrm{N}-\mathrm{Cd}-\mathrm{N}$ angles within the coordination sphere

Angle

\begin{tabular}{llllllrr}
\hline$N(1)[0.04$, & $0.09,0.17]$ & $-C d[0.00,0.00,0.00]$ & $-N(3)[0.12$, & -0.09, & $0.03]$ & $92.8(0.6)$ \\
$N(1)[0.04$, & $0.09,0.17]$ & $-C d[0.00,0.00,0.00]$ & $-N(3)[-0.12$, & 0.09, & $-0.03]$ & $87.2(0.6)$ \\
$N(1)[0.04$, & $0.09,0.17]$ & $-C d[0.00,0.00,0.00]$ & $-N(4)[-0.08$, & -0.08, & $0.15]$ & $89.9(0.5)$ \\
$N(1)[0.04$, & $0.09,0.17]$ & $-C d[0.00,0.00,0.00]$ & $-N(4)[0.08$, & 0.08, & $-0.15]$ & $90.1(0.5)$ \\
$N(3)[0.12$, & $-0.09,0.03]$ & $-C d[0.00,0.00,0.00]$ & $-N(4)[-0.08,-0.08$, & $0.15]$ & $92.2(0.5)$ \\
$N(3)[0.12$, & $-0.09,0.03]$ & $-C d[0.00,0.00,0.00]$ & $-N(4)[0.08$, & 0.08, & $-0.15]$ & $87.8(0.5)$ \\
\hline
\end{tabular}

b) $\mathrm{Cd}-\mathrm{N}-\mathrm{N}$ and $\mathrm{N}-\mathrm{N}-\mathrm{N}$ angles for the azide groups

\begin{tabular}{llllllll}
\hline $\mathrm{Cd}[0.00,0.00,0.00]$ & $-\mathrm{N}(1)[0.04,0.09,0.17]$ & $-\mathrm{N}(2)[$ & 0.10, & 0.11, & $0.22]$ & $138.9(1.3)$ \\
$\mathrm{Cd}[0.25,0.25,0.25]$ & $-\mathrm{N}(3)[0.16,0.13,0.28]$ & $-\mathrm{N}(2)[$ & 0.10, & 0.11, & $0.22]$ & $129.0(1.3)$ \\
$\mathrm{N}(1)[0.04,0.09,0.17]$ & $-\mathrm{N}(2)[0.10,0.11,0.22]$ & $-\mathrm{N}(3)[$ & 0.16, & 0.13, & $0.28]$ & $179.1(1.7)$ \\
\hline
\end{tabular}

c) Angles within the pyridine ring

\begin{tabular}{lllllllll}
\hline $\mathrm{C}(1)[0.21$, & $0.38,0.49]$ & $-\mathrm{N}(4)[0.17,0.33,0.40]$ & $-\mathrm{C}(5)[$ & 0.09, & 0.33, & $0.40]$ & $118.6(1.4)$ \\
$\mathrm{N}(4)[0.17$, & $0.33,0.40]$ & $-\mathrm{C}(1)[0.21,0.38,0.49]$ & $-\mathrm{C}(2)[$ & 0.16, & 0.42, & $0.58]$ & $122.5(1.6)$ \\
$\mathrm{C}(1)[0.21$, & $0.38,0.49]$ & $-\mathrm{C}(2)[0.16,0.42,0.58]$ & $-\mathrm{C}(3)[$ & 0.07, & 0.42, & $0.58]$ & $119.2(1.8)$ \\
$\mathrm{C}(2)[0.16$, & $0.42,0.58]$ & $-\mathrm{C}(3)[0.07,0.42,0.58]$ & $-\mathrm{C}(4)[$ & 0.04, & 0.37, & $0.49]$ & $118.8(1.8)$ \\
$\mathrm{C}(3)[0.07$, & $0.42,0.58]$ & $-\mathrm{C}(4)[0.04,0.37,0.49]$ & $-\mathrm{C}(5)[$ & 0.09, & 0.33, & $0.40]$ & $116.9(1.7)$ \\
$\mathrm{N}(4)[0.17$, & $0.33,0.40]$ & $-\mathrm{C}(5)[0.09,0.33,0.40]$ & $-\mathrm{C}(4)[$ & 0.04, & 0.37, & $0.49]$ & $124.0(1.6)$ \\
\hline
\end{tabular}

Table 6. Best least squares plane through the pyridine ring (Cartesian coordinates in $\AA$ ) and deviations from this plane. Numbers in square brackets indicate position in Cartesian coordinates in $\AA$.

$$
-0.7797 X-0.0071 Y-0.6261 Z=-9.4204
$$

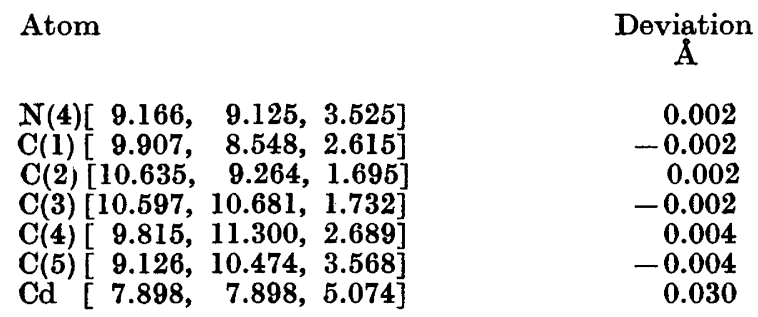

due to the azide group. An azide group is supposed to show a very strong band due to antisymmetric stretching $\left(\nu_{3}\right)$ just above $2000 \mathrm{~cm}^{-1}$ and a weaker band due to symmetric stretching $\left(\nu_{1}\right)$ around or a little above $1300 \mathrm{~cm}^{-1}$. The symmetric stretching band vanishes in IR for symmetric azides. A weaker band due to bending $\left(v_{2}\right)$ of the azide group is also to be found just above $600 \mathrm{~cm}^{-1}{ }^{14,15}$

In the IR-spectrum of $\left[\mathrm{Cd}\left(\mathrm{N}_{3}\right)_{2}\left(\mathrm{C}_{5} \mathrm{H}_{5} \mathrm{~N}\right)_{2}\right]$ the strong antisymmetric azide stretching band is observed at $2055 \mathrm{~cm}^{-1}$. There is no obvious peak due to symmetric stretching, and the weak band due to bending is a little difficult to 
distinguish, because of the absorption of pyridine in this region, but a slightly split band at $630 \mathrm{~cm}^{-1}$ might be due to overlap of a pyridine band with the bending band of the azide group.

The IR-spectrum will be discussed later, after the structure of $\left[\mathrm{Cd}\left(\mathrm{N}_{3}\right)_{2}\left(\mathrm{C}_{5} \mathrm{H}_{5} \mathrm{~N}\right)_{2}\right]$ has been described.

\section{DESCRIPTION OF THE STRUCTURE AND DISCUSSION}

The cadmium atom in $\left[\mathrm{Cd}\left(\mathrm{N}_{3}\right)_{2}\left(\mathrm{C}_{5} \mathrm{H}_{5} \mathrm{~N}\right)_{2}\right]$ is surrounded by an octahedral configuration of six nitrogen atoms (Fig. 3). Four of the surrounding nitrogen

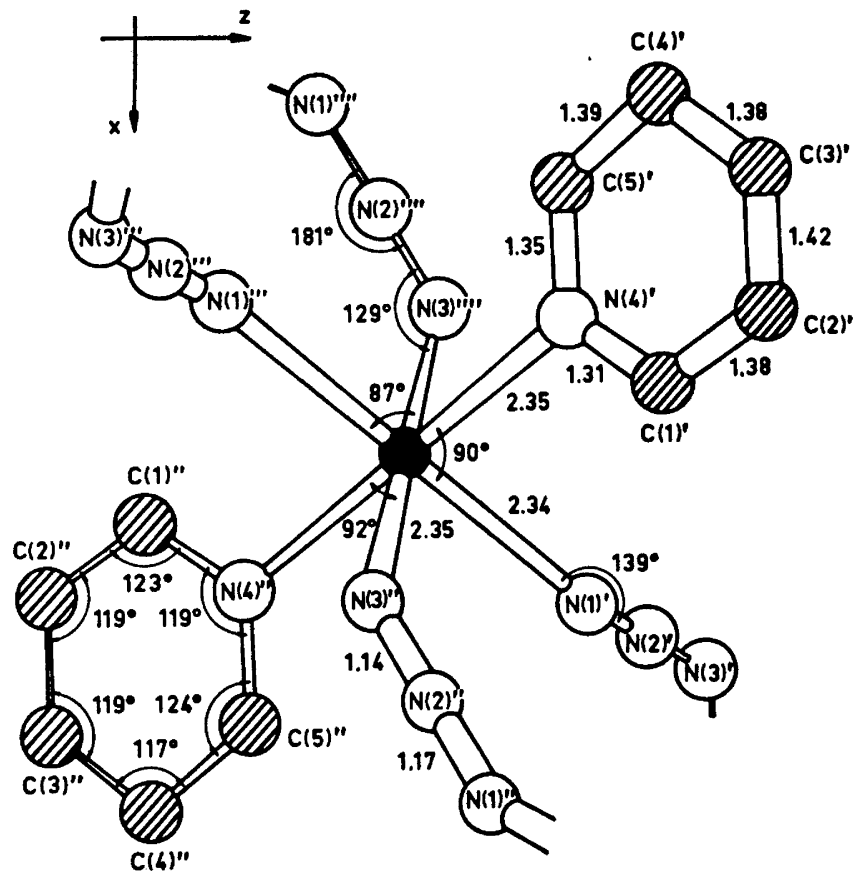

Fig. 3. The configuration around the cadmium atom in $\left[\mathrm{Cd}\left(\mathrm{N}_{3}\right)_{2}\left(\mathrm{C}_{5} \mathrm{H}_{5} \mathrm{~N}\right)_{2}\right]$ as projected along the $b$-axis. Distances in $\AA$.

atoms are end atoms of azide groups, while the other two are nitrogen atoms of pyridine rings. The distances from the cadmium atom to the nitrogen atoms of the azide groups are $\mathrm{Cd}-\mathrm{N}(1) 2.336 \pm 0.017 \AA, \mathrm{Cd}-\mathrm{N}(3) 2.352 \pm 0.016 \AA$ and to the nitrogen atoms of the pyridine rings, $\mathrm{Cd}-\mathrm{N}(4) 2.349 \pm 0.012 \AA$ (Table 4). An octahedral configuration of ligands is common in cadmium complexes, and in an approximate determination of the $\mathrm{Cd}-\mathrm{N}$ distance in the octahedral complex $\mathrm{Cd}\left[\mathrm{SC}\left(\mathrm{NHCH}_{2}\right)_{2}\right]_{2}(\mathrm{NCS})_{2}$ the value $2.5 \pm 0.1 \AA$ is reported. ${ }^{16}$ 
There seems to be no difference in the distances between the cadmium atom and the nitrogen atoms of the two different ligands. In the azide-pyridine complexes investigated earlier, $\left[\mathrm{Cu}\left(\mathrm{N}_{3}\right)_{2}\left(\mathrm{C}_{5} \mathrm{H}_{5} \mathrm{~N}\right)_{2}\right]^{4}$ and $\left[\mathrm{Zn}\left(\mathrm{N}_{3}\right)_{2}\left(\mathrm{C}_{5} \mathrm{H}_{5} \mathrm{~N}_{2}\right]^{5}\right.$ the bond lengths from the central atom to the nitrogen atoms of the azide ligands appeared to be shorter than those to the pyridine ligands. In the cadmium complex, however, the azide group is bonded equally within the limits of error to two cadmium atoms, one at each end, while in the copper and zinc complexes, the azide group is bonded principally to one central atom through one end.

The structure can be visualised as being built up by linking of the cadmium octahedra, through four corners, by azide groups, to form a three-dimensional network. The pyridine rings are attached to the two remaining corners of the octahedra (Fig. 4) and packed at van der Waals distances from the azide

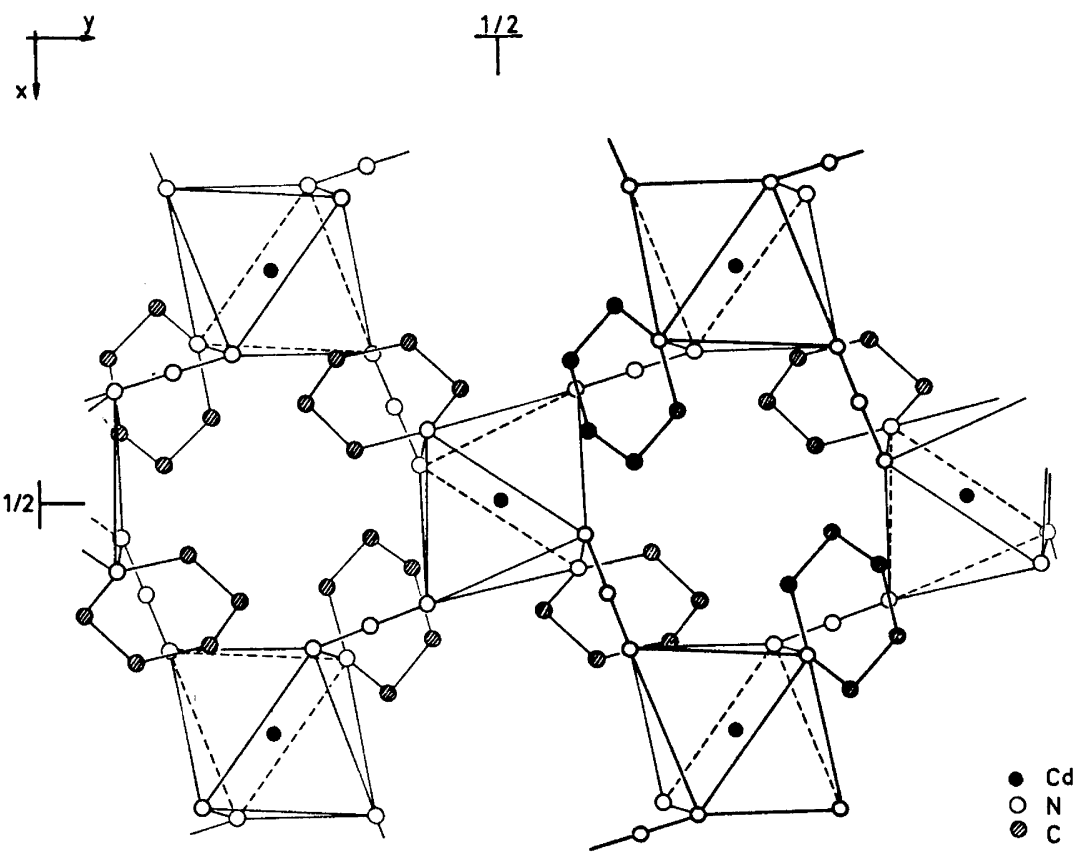

Fig. 4. A projection along the c-axis illustrating the coupling of the cadmium-nitrogen octahedra by azide groups, and the packing of the pyridine rings.

groups, the $\mathrm{C} \cdots \mathrm{N}$ distances being $3.3 \AA$ and $3.4 \AA$ (Table 4 ). The rings are inclined to one another, the angle between the planes of two neighbouring rings being $67^{\circ}$, and the shortest distances between two carbon atoms of different rings being $3.6 \AA$.

The azide group appears to be linear and symmetrical, which is supported by the IR-spectrum. The nitrogen-nitrogen distances found are $\mathrm{N}(1)-\mathrm{N}(2)$ $1.167 \pm 0.020 \AA$ and $\mathrm{N}(2)-\mathrm{N}(3) \quad 1.141 \pm 0.021 \AA$ (Table 4) and the 
$\mathrm{N}(1)-\mathrm{N}(2)-\mathrm{N}(3)$ angle is $179.1 \pm 1.7^{\circ}$ (Table 5). The azide group is coordinated at each end to a different, approximately equally remote cadmium atom.

It appears natural that an azide group which is coordinated equally at both ends is symmetric, whereas an azide group which is not coordinated equally at both ends tends to be asymmetric, and that the longer nitrogennitrogen distance is that corresponding to the end in which the azide is most strongly bonded. ${ }^{21}$ This is illustrated in Fig. 5, which shows, schematically,
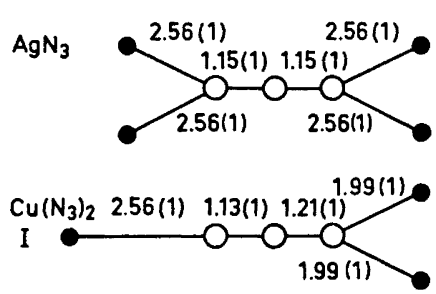

$2.00(1)$

II

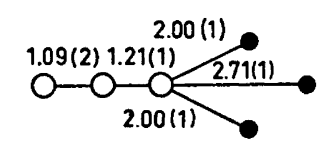

$\mathrm{O} N$

- Me

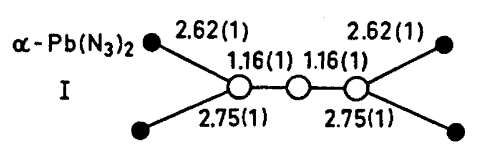

II
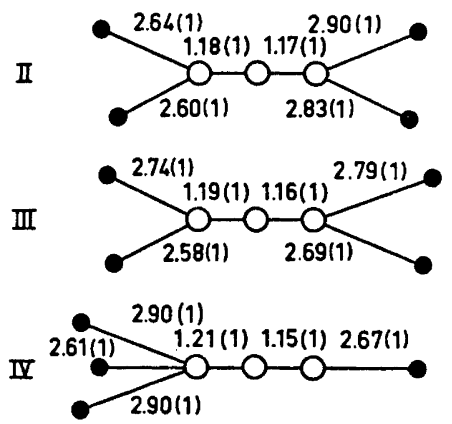

Fig. 5. Schematic illustration of the coordination of the azide groups and the bond lengths in three explosive metal azides.

the coordination of the azide group and the bond lengths in three different azides of heavy metals, and it may be noticed, that they are all three explosive, although both symmetric and asymmetric azide groups are represented among them. In $\mathrm{AgN}_{3},{ }^{17,23}$ for instance, the azide group is equally coordinated at both ends and was found to be symmetric. In $\mathrm{Cu}\left(\mathrm{N}_{3}\right)_{2},{ }^{3}$ however, both azide groups are coordinated differently at each end and were found to be asymmetric, the degree of asymmetry being related to the difference in strength of the bonds to the metal atoms. In $\alpha-\mathrm{Pb}\left(\mathrm{N}_{3}\right)_{2}{ }^{18}$ both symmetric and asymmetric azide groups are present, and a similar relationship between asymmetry and bonding of the azide group is found. In the azide complexes investigated earlier by the author ${ }^{1,2,4,5}$ the azide groups have all been coordinated unequally at both ends and have been found to be asymmetric.

The angle between the $\mathrm{Cd}-\mathrm{N}$ bond and the azide axis is $139 \pm 1^{\circ}$ at $\mathrm{N}(1)$ and $129 \pm 1^{\circ}$ at $\mathrm{N}(3)$. The corresponding values reported are generally around $120^{\circ}$, though they vary over a wide range, and values even larger than those found in $\left[\mathrm{Cd}\left(\mathrm{N}_{3}\right)_{2}\left(\mathrm{C}_{5} \mathrm{H}_{5} \mathrm{~N}\right)_{2}\right]$ have been reported in cases where the azide group is strongly coordinated at more than one end, e.g. $\alpha-\mathrm{Pb}\left(\mathrm{N}_{3}\right)_{2} \cdot{ }^{18}$

The pyridine ring is planar, within the limits of error, and the best plane through the atoms of the ring was obtained by least squares calculations, 
using the programme PLANEFIT ${ }^{12}$ (Table 6). Distances and angles within the ring (Tables 4 and 5 ) are in agreement with those found in the structures of $\left[\mathrm{Cu}\left(\mathrm{N}_{3}\right)_{2}\left(\mathrm{C}_{5} \mathrm{H}_{5} \mathrm{~N}\right)_{2}\right]^{4}$ and $\left[\mathrm{Zn}\left(\mathrm{N}_{3}\right)_{2}\left(\mathrm{C}_{5} \mathrm{H}_{5} \mathrm{~N}\right)_{2}\right]^{5}$ and those reported for pure pyridine. ${ }^{10,20}$

The two pyridine rings coordinated to the same central atom are coplanar, owing to symmetry reasons, and the central cadmium atom is situated approximately in the plane of the pyridine rings, the perpendicular distance from the plane of the rings to the cadmium atom being $0.03 \AA$. The plane of the pyridine ring is inclined at angles of $43^{\circ}$ and $44^{\circ}$, respectively, to the two square planes in the octahedron containing the central cadmium atom and the nitrogen atoms of the pyridine rings, i.e. the planes through the nitrogen atoms $\mathrm{N}(4)^{\prime}, \mathrm{N}(4)^{\prime \prime}, \mathrm{N}(1)^{\prime}$, and $\mathrm{N}(1)^{\prime \prime \prime}$ and the nitrogen atoms $\mathrm{N}(4)^{\prime}, \mathrm{N}(4)^{\prime \prime}$, $\mathrm{N}(3)^{\prime \prime}$, and $\mathrm{N}(3)^{\prime \prime \prime \prime}$ (cf. Fig. 3). A similar rotation of the plane of the pyridine ring was observed in $\left[\mathrm{Cu}\left(\mathrm{N}_{3}\right)_{2}\left(\mathrm{C}_{5} \mathrm{H}_{5} \mathrm{~N}\right)_{2}\right]$, where the inclination was $43^{\circ}$ with respect to the plane containing the central copper atom and its four nearest nitrogen atoms.

A comparison of the IR-spectrum of $\left[\mathrm{Cd}\left(\mathrm{N}_{3}\right)_{8}\left(\mathrm{C}_{5} \mathrm{H}_{5} \mathrm{~N}\right)_{2}\right]$ with those of $\left[\mathrm{Cu}\left(\mathrm{N}_{3}\right)_{2}\left(\mathrm{C}_{5} \mathrm{H}_{5} \mathrm{~N}\right)_{2}\right]^{4}$ and $\left[\mathrm{Zn}\left(\mathrm{N}_{3}\right)_{2}\left(\mathrm{C}_{5} \mathrm{H}_{5} \mathrm{~N}\right)_{2}\right]^{5}$ reveals a close agreement between absorbing frequencies, but it is also possible to detect differences in the spectra due to structural inequalities between the three complexes.

Thus, in the cadmium complex the pyridine rings, as well as the azide groups, are crystallographically equivalent, and the azide group is bonded in both ends at approximately equal distances to two different cadmium atoms. In the copper complex the pyridine rings are crystallographically equivalent, while the two azide groups are crystallographically independent. The azide groups are differently coordinated, but both are bonded more strongly to one copper atom at one end. Finally, in the zinc complex, both the two pyridine rings and the two azide groups are crystallographically different, and the azide groups are bonded to one zinc atom in one end only.

When examining the peaks originating from the pyridine ligands in the IR-spectra of the three compounds, it is found that they occur at almost exactly the same frequencies. In the spectrum of the zinc complex, however, most of the pyridine peaks are split, which is not observed in the spectra of the other two compounds.

The strong antisymmetric stretching band $\left(v_{3}\right)$ of the azide group is in all three compounds observed between $2100 \mathrm{~cm}^{-1}$ and $2030 \mathrm{~cm}^{-1}$. Owing to the structures of the complexes, it is expected to be split for the copper and zinc complexes but not for the cadmium complex, this is supported by the spectra, except that for the copper complex the band appears as a single, although slightly broadened band.

The symmetric azide stretching band $\left(\nu_{1}\right)$ is registered between $1350 \mathrm{~cm}^{-1}$ and $1330 \mathrm{~cm}^{-1}$ in the copper and zinc compounds and, as expected, it is split for both compounds. The symmetric stretching is not observed for the cadmium complex, which is in accordance with its symmetrical coordination.

A very weak bending band $\left(v_{2}\right)$ is, for all three compounds, found in the region $630-610 \mathrm{~cm}^{-1}$. 
All computer calculations have been performed on an IBM 360/50 computer at the Göteborg Universities' Computing Centre.

Acknowledgements. I wish to thank Professor Cyrill Brosset for all the facilities put at my disposal. I also wish to express my thanks to Professor Georg Lundgren and Professor Nils-Gösta Vannerberg for their encouragement and most helpful advice. Many thanks are due to Fil. mag. Birgitta Svensson for valuable assistance, to Mrs. Margareta Bieth for skilful help with the collection of the data, and to Dr. Susan Jagner for revising the English text of this paper.

Financial support in the form of grants from the Swedish Natural Science Research

Council (Contract No. 2286-14), Ograduerade forskares fond, and Chalmers University of Technology, the last to cover the costs of the computer work, is gratefully acknowledged.

\section{REFERENCES}

1. Agrell, I. Acta Chem. Scand. 20 (1966) 1281.

2. Agrell, I. Acta Chem. Scand. 21 (1967) 2647.

3. Agrell, I. and Lamnevik, S. Acta Chem. Scand. 22 (1968) 2038.

4. Agrell, I. Acta Chem. Scand. 23 (1969) 1667.

5. Agrell, I. Acta Chem. Scand. 24 (1970) 1247.

6. Curtius, T. and Rissom, J. J. prakt. Chem. [2] 58 (1898) 294.

7. Strecker, W. and Schwinn, E. J. prakt. Chem. 152 (1939) 213.

8. Schwarzenbach, G. Die komplexometrische Titration, Ferdinand Enke, Stuttgart 1956, p. 78.

9. Arnold, J. W. Ind. Eng. Chem. Anal. Ed. 17 (1945) 215.

10. Svensson, B. Unpublished work.

11. Berggren, J. To be published.

12. Modified programmes in use at this Department. POWDER was originally written by Lindqvist, O. and Wengelin, F.; DATA P2 by Coppens, P., Leiserowitz, L. and Rabinowich, D.; DRF by Zalkin, A.; LALS by Gantzel, R., Sparks, K. and Trueblood, K.; DISTAN by Zalkin, A.; and PLANEFIT by Wengelin, $F$.

13. Doyle, P. A. and Turner, P. S. Acta Cryst. A 24 (1968) 390.

14. Gray, P. and Waddington, T. C. Trans. Faraday Soc. 53 (1957) 901.

15. Yoffe, A. D. Developments in Inorganic Nitrogen Chem. 1 (1966) 107.

16. Tables of Interatomic Distances and Configuration in Molecules and Ions, The Chemical Society, London, Suppl. 1956-1959.

17. Hughes, E. W. Personal communication to Söderquist, R. (1966).

18. Choi, C. S. and Boutin, H. P. Acta Cryst. B 25 (1969) 982.

19. Bak, B., Hansen, L. and Rastrup-Andersen, I. J. Chem. Phys. 22 (1954) 2013.

20. Liquori, A. M. and Vaciago, A. Ric. Sci. 26 (1956) 1848.

21. Griffith, W. P. Developments in Inorganic Nitrogen Chem. 1 (1966) 265.

22. International Tables for $X$-Ray Crystallography, Kynoch Press, Birmingham 1959.

23. Söderquist, R. Symp. Chem. Probl. Connected Stabil. Expl. lst Ed., Hansson, J., Stockholm 1967.

Received April 23, 1970. 